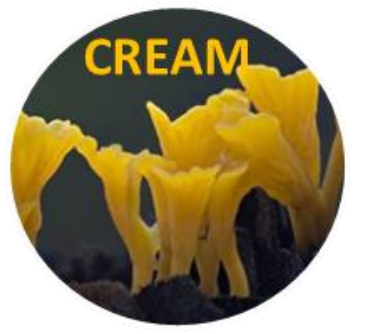

Current Research in Environmental \& Applied Mycology 6 (2): 143-149(2016) ISSN 2229-2225

www.creamjournal.org

Article

CREAM

Copyright $(C) 2016$

Doi 10.5943/cream/6/2/8

\title{
Glomus segmentatum, rediscovery of a rare epigeous sporocarpic fungus to Cuba
}

\author{
Furrazola $E^{1}$, Torres-Arias $\mathbf{Y}^{1}$, Thoen, $\mathrm{D}^{2}$, Berbara $\mathbf{R L L}^{3}, \mathrm{Jobim}, \mathrm{K}^{4}$ and Goto $\mathrm{BT}^{4}$ \\ ${ }^{1}$ Instituto de Ecología y Sistemática de Ciudad de La Habana, A.P. 11900, La Habana, Cuba \\ ${ }^{2}$ Département des Sciences et Gestion de L'Environnement, Université de Liège, Campus d'Arlon, 6700 Arlon, Belgium \\ ${ }^{3}$ Departamento de Ciências do Solo, Universidade Federal Rural do Rio de Janeiro, Seropédica, Rio de Janeiro, Brazil \\ ${ }^{4}$ Programa de Pós-graduação em Sistemática e Evolução, CB, Universidade Federal do Rio Grande do Norte, Campus \\ Universitário, 59072-970, Natal, RN, Brazil
}

Furrazola E, Torres-Arias Y, Thoen D, Berbara RLL, Jobim K, Goto BT 2016 - Glomus segmentatum, rediscovery of a rare epigeous sporocarpic fungus to Cuba. Current Research in Environmental \& Applied Mycology 6(1), 143-149, Doi 10.5943/cream/6/2/8

\begin{abstract}
Cuba has shown in several studies a high diversity of arbuscular mycorrhizal fungi, related with its high plant endemism. During diversity studies of the epigeous mycota an rare sporocarpic arbuscular mycorrhizal fungi species was found in San Andrés, western Cuba associated to Quercus cubana in a holm-oak wood. The fungus identified as Glomus segmentatum forms large sporocarps (3.5 $\times 6 \mathrm{~mm}$ ) over soil surface and 8-16 polyhedral segments interconnected by basal hypha. Its globose to subglobose glomerospores (55-)65(-82) $\mu \mathrm{m}$ have three spore wall layers: an outer (swl1) evanescent, hyaline up to $1 \mu \mathrm{m}$ layer, a second laminate layer (swl2), dull white to yellowish white 3.6-7.5 $\mu \mathrm{m}$ thick and yellowish white $0.5-1.0 \mu \mathrm{m}$ inner layer (swl3). Subtending hypha is hyaline to white, 7.5$16.8 \mu \mathrm{m}$ at spore base, continuous with spore wall layers (swl1-swl2), 2.8-4 $\mu \mathrm{m}$ thick, at the point of attachment, from this point gradually thins up to $0.5 \mu \mathrm{m}$ thick. This study provides additional taxonomic information of a rare fungus and represents a new occurrence data for Cuba and the second global record for the species.
\end{abstract}

Key words - Caribbean - diversity - Glomerales - morphology - taxonomy

\section{Introduction}

Schüßler et al. (2001) established the phylum Glomeromycota in order to place arbuscular mycorrhizal fungi (AMF). Actually, with five orders (Archaeosporales, Diversisporales, Gigasporales, Glomerales and Paraglomerales) within three classes Archaeosporomycetes, Glomeromycetes and Paraglomeromycetes (Oehl et al. 2011a). Within the Glomeromycota, there is a high phyletic variability of sporocarps species, notably species with glomoid spore formation (Glomus, Sclerocystis, Rhizoglomus and Redeckera) (Goto \& Maia 2005, Oehl et al. 2011a,b, Goto et al. 2016). Therefore, the glomeromycotan sporocarps demand a cautious interpretation of its taxonomic characters (Morton \& Benny 1990).

Cuba, which has the highest plant diversity in the Caribbean, is considered among the four islands with the largest plant species number in the World (CITMA 2014). In 2010 were reported 5778 plant native taxa with a 51.4\% of endemics (Acevedo-Rodríguez \& Strong 2010). According to that, glomeromycotan fungi diversity is also high and until now has been observed more than 70 AMF in Cuba (CITMA 2014). Arbuscular mycorrhizal fungi has been studied many years ago in Cuba (Ferrer 
\& Herrera 1980, 1988, Herrera et al. 2003, Furrazola et al. 2011a, b, 2013, Rodríguez et al. 2011, Torres-Arias et al. 2015) resulting in several new species, but any sporocarpic species has detected at moment.

AMF diversity studies emphasizing sporocarpic species are rare due to the methodology used (soil collection only) neglecting the active search for epigeous or semi-hypogeous sporocarps. For this reason, exhaustive soil samplings looking for epigeal sporocarpic species were developed in western Cuban belonging to San Andrés, La Palma municipality, Pinar del Río province, were surveyed for arbuscular mycorrhizal (AM) fungi within a study of diversity and ecology. A certain number of a typical glomeromycotan sporocarps found during these works were studied deeply and some of them resulting Glomus segmentatum Trappe, Spooner \& Ivory. Originally G. segmentatum was found during mycological studies developed in Belize, Central America (Trappe 1979). This species was isolated, solitary on bare soil surface at the edge of a bank near Pinus caribaea Morelet and other shrubs, herbs and grass. Since then, that species were not reported again from any place of the world.

The protologue of $G$. segmentatum does not described many morphological features used actually in AMF taxonomic papers. Some biogeographics data to support the presence of that species both in Belize and in Cuba are showed in our discussion. For this reason, the subject was to described G. segmentatum using the morphological data set made available recently by Oehl et al. (2011a, b, c), improving morphological data and distribution to that rare fungus.

\section{Materials \& Methods}

San Andrés is located in western Cuba near to Sierra de los Organos, in a region within Guaniguanico mountainous group $\left(3710 \mathrm{~km}^{2}\right)$. That region belongs to phytogeographic subprovince Cuba occidental (Occidento-Cubanicum) (Borhidi 1991). The central nucleus of that mountains represent two thirds of Pinar del Río province surface, and are surrounded by marginal prairies which fill the rest of the province (Urquiola et al. 2010).

According to these authors Sierra de los Órganos sensu lato lithology present two definite units: Alturas de Pizarras and Sierra de Los Órganos sensu stricto. The former comprise $80 \%$ of the area and it is formed by quartzitic rocks, clays and quartz fragments while the latter knowing like Faja de Mogotes occupy $570 \mathrm{~km}^{2}$ only and it is composed by limestone rocks. The studied area is located inside facial tectonic zone from Guaniguanico, presenting in it the complexes of knowing units Sierra de los Organos and Sierra de Guacamaya (Gutiérrez \& Rivero 1995).

This large strip like an arch have climatic variations as consequence of differences in rain values, being the annual mean $1500 \mathrm{~mm}$ approximately. Climate is warm and humid with two seasons well defined: one warm and rainy and other fresh and less rainy with values higher than the rest of Pinar del Río province (Samek \& Travieso 1968). The hydrography of this area is very important because it is included in San Diego basin with its own sub-basins formed by rivers and streams like affluent (Pimentel 2003). Like consequences of elevated rainfalls and the prevalence of clayey and clayey-sandy rocks, which represent $70 \%$ of the studied area, it has been favored a high superficial wring with the presence of rivers, streams and creeks, disrupted by calcareous zones (Ares 1999).

The complexity of karstic relief with subterranean drainage, interior dolines and transfluent caverns permit the existence of multiple ecological variations with great habits diversity. In Pinar del Río province vegetation physiognomy and its floristic composition permitting to appreciate six principals phytogeographic districts (Borhidi 1991): Guanahacabibense, Sabaloense, Pinarense, Viñalense, Cajalbanense and Rosariense. La Palma store up the largest nucleus of Cajalbanense district, join to a portion of Viñalense district (mogotes from Sierra de los Organos) and Pinarense (Alturas de Pizarra).

The studied ecosystem was an oak wood, which appears like patches in $P$. caribaea ecosystems in that country region. The sampled was developed in October 2004, at the end of the wetter period in western Cuba. Soil surface at selected areas was checked carefully in order to sample large sporocarps, both naked soils like litter fall, or organic detritus. Sporocarps were collected manually, and placed in paper bags, transported until lab and dried in oven at $70{ }^{\circ} \mathrm{C}$. Sporocarps pictures were taken under a 
dissected microscope Zeiss Axioscop using an Axiocam camera and AxioVision (v. 3.1 software at 1300 $\times 1030$ dpi) or Canon digital cameras.

Sporocarps were fragmented to study spore organization. Glomerospores were mounted on microscope slides either in water (to check unmodified characteristics of spore wall components and spore colour) (Spain 1990) or permanently in PVLG or PVLG with Melzer's reagent (Brundrett et al. 1994).

Terminology follows Oehl et al. (2011b) and Furrazola et al. (2011a). The spore denomination of Goto \& Maia (2006) was used. Zeiss Axioskop compound microscopes with or without Nomarski differential interference contrast (DIC) were used for detailed spore observations.

\section{Results}

Sporocarps on soil surface or embedded in organic matter $(3.5 \times 6 \mathrm{~mm})$, pulvinate, white to pale yellowish brown (FIG. 1) with a basal attachment of tangled, yellowish white to pale yellowish brown hyphae mixed with soil, tessellated with convex, subpolygonal areas separated by grooves $(8-16$ polyhedral segments) (FIG. 2). Each subpolygnal area presents apex $0.8-0.10 \mathrm{~mm}$, base $0.2-0.3 \mathrm{~mm}$ and lenght $0.14-0.16 \mathrm{~mm}$. A though peridium encloses crowded glomerospores embedded in interwoven hyphae. Peridium white at first, becoming yellow ochre when handled. Peridium hyphae hyaline to white, tightly parallel alongside each radial glebal segment (FIG. 3), but interwoven on the outer segment face, 3-10.3 $\mu \mathrm{m}$ wide, walls of 1-2 $\mu \mathrm{m}$ thick, rarely septate, with dichotomous or perpendicular branches and sometimes with sharpened tips (FIG. 4), staining orange to deep pink in Melzer's reagent. Gleba vivid amber yellow, composed of tightly packed tough segments radiating outward from a basal pad, the segments separable as polyhedrons with rounded outer surfaces that form the tessellate pattern of the sporocarp surface. Glomerospores hyaline to dull white formed terminally in subtending hypha (FIGS. 4-7). Glomerospores globose (55-)65(-82) $\mu \mathrm{m}$ diam to subglobose (48-68 $\times 68-87 \mu \mathrm{m})($ FIG. 8).

Spore wall is 6-12 $\mu \mathrm{m}$ thick in total and consists of three layers (FIGS. 8). The outer layer (SWL1) is ephemeral, hyaline, up to $1 \mu \mathrm{m}$ thick observed essentially in young spores. The second layer (swl2) is laminated, dull white to yellowish white, 4-10 $\mu \mathrm{m}$ thick and the third layer (swl3) is flexible, yellowish white, $0.5-1.0 \mu \mathrm{m}$ thick, commonly tightly adherent to the most internal laminae of swl2. Spore wall layers continuous with subtending hypha layers (FIG. 9). The pigmentation of swl2 is continuous with subtending hypha wall (FIGS. 7-9). Melzer reaction deep pink to red purple and present only in laminated layers in young spores recently extract from fresh sporocarps. Mature spores do not present Melzer's reaction and young spores lose reaction after one week in Melzer's reagent.

Subtending hyphae single, straight or curved, cylindrical, sometimes broken at point of attachment, hyaline to white, usually gradually widening distally, 7.5-16.8 $\mu \mathrm{m}$ wide at spore base. The colour of spore is continuous in subtending hypha. Wall of subtending hypha hyaline to white, composed of three layers continuous with spore wall layers (swl 1-3), 2.8-4.0 $\mu \mathrm{m}$ thick at the spore base, then gradually thins up to $0.5 \mu \mathrm{m}$ near the spore base, tapering to approx. $1-1.5 \mu \mathrm{m}$ distally. Pore 2.1-5.2 $\mu \mathrm{m}$ wide, open or occluded by a straight or slightly curved septum formed by swl3 (FIG. 9).

Known distribution - collected originally in Silver Creek, F.S., Belize, in October 1976, associated to Pinus caribea. In Cuba G. segmentatum was found associated to a holm-oak wood (Quercus cubana A. Rich.), which constitutes a vegetation relict associated to Pinus caribea also, in San Andrés, Pinar del Río, Cuba.

Material examined - (UFRN-Fungos 2687) Cuba, Pinar del Río, La Palma municipality, San Andrés, geographic coordinates: $22^{\circ} 40.977^{\prime} \mathrm{N} ; 8^{\circ} 35.396^{\prime} \mathrm{S}$, sporocarp superficial on bare soil, altitude: 184 m.a.s.l., date 10/09/2004, collector Dr. Daniel Thoen, collectors number (Herbier Dr. Daniel Thoen C-18).

\section{Discussion}

This is the first report of G. segmentatum for Cuba and the second known record for this species around the world. Sporocarps found in the present study were something smaller than the sporocarps described originally $(3.5 \times 6 \mathrm{~mm}$ by $6 \times 8 \mathrm{~mm})$, however they showed the typical firm structure 
described for that species. Glomus segmentatum was originally described with a spore wall composed by two components, $4-8 \mu \mathrm{m}$ thick including the outer wall, $\pm 0.5 \mu \mathrm{m}$ thick. However in Cuba material was observed with a very thin internal wall (swl3) component like has been referred by Oehl et al. (2011a), of flexible appearance until $1.0 \mu \mathrm{m}$ thick, very difficult to observe because it is commonly adhere to laminated and large swl2. Wall (swl3) was not reported in the original description f Trappe (1979).

Some species of genus Glomus forms sporocarps with a peridium and colourless to pale yellow coloured spores like G. pubescens (Sacc. \& Ellis) Trappe \& Gerd, and Glomus vesiculiferum (Thaxt.) Gerd. \& Trappe.

It is known that von Höhnel (1910) synonymized Sphaerocreas to the genus Sclerocystis. Thaxter (1922) then removed S. pubescens from the genus Sclerocystis. Zycha (1935) transferred this species to the genus Endogone, and later, Gerdemann and Trappe (1974) placed it in the genus Glomus. Recently, Oehl et al. (2011a) emended the taxonomic description of the genus Glomus based on molecular phylogenetic and morphological analysis. According to their emended description, Glomus forms typical arbuscular mycorrhiza. Although there is no evidence that $S$. pubescens forms arbuscular mycorrhiza, Oehl et al. (2011a) decided to retain S. pubescens within Glomus based on morphological analyses.

However, Hirose et al. (2014) investigated the phylogenetic position of S. pubescens from Japan. The results indicated that $S$. pubescens is a member of Mucoromycotina due to it formed an independent clade separated from the other known orders of this subphylum and it is closely related to the uncultured and unidentified Mucoromycotinan fungi recently reported as environmental DNAs in liverworts and hornworts. Nevertheless, the peridial $S$. pubescens radiate outwards its sporocarps to form pubescence and its spores are smaller than $G$. segmentatum spores.

The unique structure of $G$. vesiculiferum that readily separating this fungus from $G$. segmentatum is peridial thin-walled with ellipsoid to broadly clavate vesicles (Gerdemann and Trappe 1974). According to Oehl et al. (2011a), G. segmentatum comprises the genus characteristics in the sense that produce spores in compact sporocarps with peridium, spores with multiple layered walls. Wall of the subtending hyphae conspicuously continuous and concolorous with the spore wall, or slightly lighter in color than the spore wall. Spore pore closure often by introverted wall thickening, sometimes supported by a short bridging septum, rarely open.

Despite many controversial details, most geologists agree that the Caribbean region is a separate tectonic unit (Borhidi 1991). According with this author, the direct land connections between Cuba and Central America disappeared by the end of the Miocene. On the other hand, Iturralde-Vinent (1975, 1977) stated that Cuba has been formed of six archaic isolated blocks, Hispaniola probably of three blocks and Jamaica and Puerto Rico of one block each. In the Upper Miocene the general vertical movement started leading to the emergence of the Cayman and Nicaragua Ridge. Thus, the Cuban archipelago and Central America became connected. This process was completed in the Pliocene and then the islands started to separate finally, and the recent shape of the islands was formed in the Pleistocene. Presumably, this is the period when the South American element immigrated into Cuba via the Lesser Antilles although at that lime land strips no longer existed. That geological evolution is one of the reasons that explain the similitude between the floras of Central America and Cuba, an in consequence, the presence of similar AMF species.

Quercus cubana is a Cuban endemic, the unique species of that genus in our country and constitutes a vegetation relict associated commonly to $P$. caribea, the same species under which $G$. segmentatum was originally isolated. On the other hand, it is well established that Quercus genus forms both arbuscular (AM) and ectomycorrhizal (EM) associations. Members of the Fagaceae typically form EM with diverse fungi (Trappe, 1962). However extra- and intraradical hyphae and vesicles typical of glomeromycotan fungi occur within the roots of Fagus and Quercus seedlings (Williams \& Aldon 1976, Rothwell et al. 1983). Arbuscular mycorrhiza was observed in Quercus agrifolia Nee. as well as in Quercus rugosa Nee. according to Egerton-Warburton \& Allen (2001) and Olivera-Morales et al. (2011), respectively. 


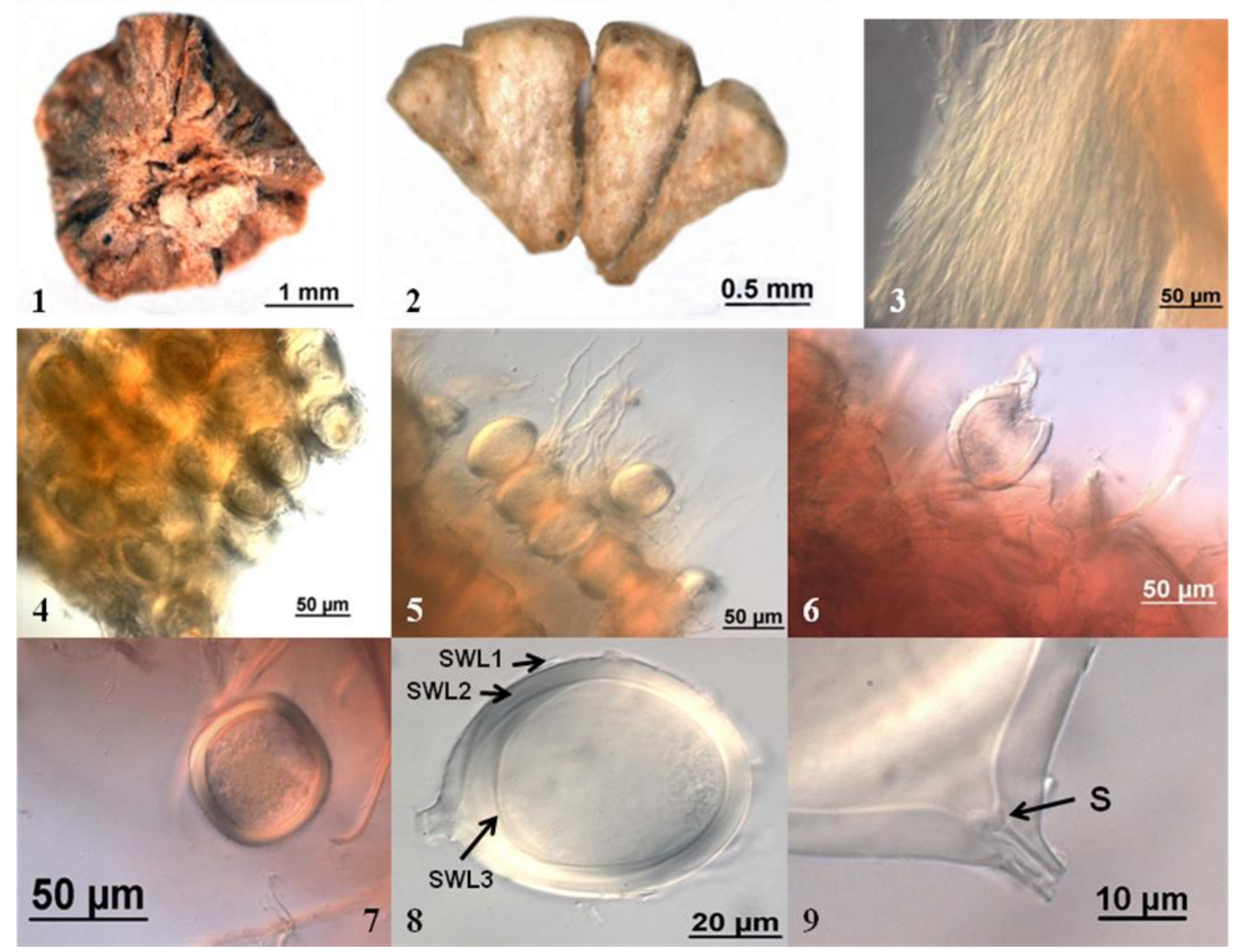

Figs 1-9-Glomus segmentatum. 1 Dissected sporocarp. 2 Sporocarps subpolygonal areas separated after crushing the sporocarp. 3 Peridium hyphae tightly parallel alongside each radial glebal segment. 4 Mature glomerospores. 5 Mature glomerospores among interwoven hyphae some of them ending in sharpened tips. 6, 7 Fragment of sporocarp and details of glomerospore in Melzer reagent. 8 Spore wall with three layers. 9 Spore wall layers continuous with subtending hypha layers and septum (s).

\section{Acknowledgements}

This work was supported by: Protax and Universal all from the Conselho Nacional de Desenvolvimento Científico e Tecnológico (CNPq) that provided research grants to BT Goto and R.L.L. Berbara.

\section{References}

Acevedo-Rodríguez P, Strong MT. 2010 - Catalogue of Seed Plants of the West Indies. Smithsonian Contributions to Botany 98, 1-1192.

Ares E. 1999 - Tablas dasométricas, propuestas de categorías y valoración de alternativas de manejo para los pinares naturales de la EFI La Palma. Tesis en opción al grado de doctor en ciencias forestales. Universidad de Pinar del Río.

Borhidi A. 1991 - Phytogeography and vegetation ecology of Cuba. Akadémiai Kiadó, Budapest.

Brundrett M, Melville I, Peterson I. 1994 - Practical Methods in Mycorrhizal Research. - University of Guelph, Mycologue Publications, Guelph, Ontario.

CITMA. 2014 - V Informe Nacional al Convenio sobre la Diversidad Biológica, La Habana, Cuba.

Egerton-Warburton L, Allen MF. 2001 - Endo- and ectomycorrhizas in Quercus agrifolia Nee. (Fagaceae): patterns of root colonization and effects on seedling growth. Mycorrhiza 11, 283-290. 
Ferrer R, Herrera RA 1980 - El género Gigaspora Gerdemann et Trappe (Endogonaceae) en Cuba. Revista del Jardín Botánico Nacional 1, 43-66.

Ferrer RL, Herrera RA. 1988 - Micotrofia en Sierra del Rosario - In: Ecología de los bosques siempreverdes de la Sierra del Rosario, Cuba. Proyecto MAB No. 1, 1974-1987. Capítulo 22, pp. 473-484. ROSTLAC Montevideo, Uruguay.

Furrazola E, Ferrer RS, Manso MOO, Torres-Arias Y, Albernas EC, Herrera RA. 2011b - Arbuscular mycorrhizal fungi species (Glomeromycota) from an agroecosystem at Havana province, with a new report for Cuba, Glomus glomerulatum. Acta Botánica Cubana 210, 26-30.

Furrazola E, Goto BT, Silva GA, Torres-Arias Y, Morais T, Lima CE, Almeida AC, Maia LC, Sieverding E, Oehl F. 2013 - Acaulospora herrerae, a new pitted species in the Glomeromycetes from Cuba and Brazil. Nova Hedwigia 97, 401-413.

Furrazola E, Torres-Arias Y, Ferrer RL, Herrera RA, Berbara RLL, Goto BT. 2011a - Glomus crenatum (Glomeromycetes), a new ornamented species from Cuba. Mycotaxon 116, 143-149.

Gerdemann JW, Trappe JM. 1974 - The Endogonaceae in the Pacific Northwest. Mycologia Memoir $5,1-76$.

Goto BT, Bezerra JL, Maia LC. 2016 - Sclerocystis coremioides (Glomeromycota) formando esporocarpos epígeos em substratos orgânicos de cacaueiro na Mata Atlântica da Bahia. Agrotrópica (Itabuna). Agrotrópica 28, 23-28.

Goto BT, Maia LC. 2005 - Sporocarpic species of arbuscular mycorrhizal fungi (Glomeromycota), with a new report from Brazil. Acta Botanica Brasilica 19, 633-637.

Goto BT, Maia LC. 2006 - Glomerospores, a new denomination for the spores of Glomeromycota, a group molecularly distinct from Zygomycota. Mycotaxon 96, 129-132.

Gutiérrez RD, Rivero GM. 1995 - Mini geografía de Cuba. Ed, Ciencia y Técnica. La Habana. Cuba.

Herrera RA, Ferrer RL, Sieverding E. 2003 - Glomus brohultii: A new species in the arbuscular mycorrhizal forming Glomerales. Journal of Applied Botany 77, 37-40.

Hirose D, Degawa Y, Yamamoto K, Yamada A. 2014 - Sphaerocreas pubescens is a member of the Mucoromycotina closely related to fungi associated with liverworts and hornworts. Mycoscience 55, 221-226.

Iturralde-Vinent, MA 1975 - Problemas de aplicación de dos hipótesis tectónicas modernas a Cuba y la región Caribe. Revista Tecnológica 13, 46-63.

Iturralde-Vinent, MA 1977 - Los movimientos tectónicos de la etapa de desarrollo platafórmico en Cuba . Informes Científicos-Técnicos No 20, Academia de Ciencias de Cuba.

Morton JB, Benny GL. 1990 - Revised classification of arbuscular mycorrhizal fungi (Zygomycetes). A new order, Glomales, two new suborders, Glominae and Gigasporinae, and two new families, Acaulosporaceae and Gigasporaceae, with an emendation of Glomaceae. Mycotaxon 37, 471491.

Oehl F, Silva GA, Goto BT, Sieverding E 2011c - New recombination in Glomeromycota. Mycotaxon 117, 429-434.

Oehl F, Silva GA, Goto BT, Sieverding E. 2011a - Glomeromycetes: three new genera an glomoid species reorganized. Mycotaxon 116, 75-120.

Oehl F, Silva GA, Sánchez-Castro I, Goto BT, Maia LC, Vieira HEE, Barea JM Sieverding E, Palenzuela J. 2011b - Revision of Glomeromycetes with entrophosporoid and glomoid spore formation with three new genera. Mycotaxon 117, 297-316.

Olivera-Morales D, Castillo-Argüero S, Guadarrama P, Ramos-Zapata J, Álvarez-Sánchez J, Hernández-Cuevas L. 2011 - Establecimiento de plántulas de Quercus rugosa Née inoculadas con hongos micorrizógenos arbusculares en un bosque templado de México. Boletín de la Sociedad Botánica de México 89, 115-121.

Pimentel O. 2003 - Medidas biotécnicas en áreas protegidas cubanas. Ed. ENPPFF. La Habana.

Rodríguez Y, Dalpé Y, Séguin S, Fernández K, Fernández F, Rivera RA. 2011 - Glomus cubense sp. nov., an arbuscular mycorrhizal fungus from Cuba. Mycotaxon 118, 337-347. DOI 10.5248/118.337. 
Rothwell FM, Hacskaylo E, Fisher D. 1983 - Ecto- and endomycorrhizal fungus associations with Quercus imbricaria L. Plant Soil 71, 309-312.

Samek V, Travieso A. 1968 - Climaregiones de Cuba. Revista Agricultura 2, 5-23.

Schüßler A, Schwarzott D, Walker C. 2001- A new fungal phylum, the Glomeromycota: phylogeny and evolution. Mycological Research 105, 1413-1421.

Spain JL. 1990 - Arguments for diagnoses based on unaltered wall structures. - Mycotaxon 38, 71-76.

Thaxter R, 1922 - A revision of the Endogoneae. Proceedings of the American Academy of Arts and Sciences 57, 291-350.

Torres-Arias Y, Ortega-Fors R, González González S, Furrazola Gómez E. 2015 - Diversity of arbuscular mycorrhizal fungi (Glomeromycota) in semicaducifolius forest of Ciénaga de Zapata, Cuba. Revista del Jardín Botánico Nacional 36, 195-200.

Trappe JM. 1962 - Fungus associates of ectotrophic mycorrhizae. Botanical Review 28, 538-606.

Trappe JM. 1979 - Glomus segmentatum sp. nov. Transactions of the British Mycological Society 73, $362-363$.

Urquiola AJ, González-Oliva L, Novo R, Acosta Z. 2010 - Libro rojo de la flora vascular de la provincia de Pinar del Río. Cuba, Jardín Botánico de Pinar del Río: Publicaciones Universidad de Alicante.

von Höhnel F, 1910 - Sitzungsberichte. Fragmente zur Mykologie. Kaiserliche Akademie der Wissenschaften in Wien, Mathematisch-Naturwissenschaftliche Klasse 119, 398-399.

Williams SE, Aldon EF. 1976 - Endomycorrhizal (vesicular-arbuscular) associations of some arid zone shrubs. Southwest Nat 20, 437-444.

Zycha H. 1935 - Mucorineae. Gebrüder Borntraeger, Leipzig. 